\title{
ROLE OF MYO-INOSITOL IN PATIENTS WITH POLYCYSTIC OVARY SYNDROME
}

Madhavi. G.B. ${ }^{1}$, Shamili. G ${ }^{* 2}$, Ramadevi. E ${ }^{3}$, Jyothi ${ }^{4}$.

${ }^{1}$ Professor in Department Of Obstetrics and Gynaecology, Chalmeda Anand Rao Institute Of Medical Sciences, Karimnagar, Telangana, India.

${ }^{* 2}$ Post Graduate Student in Department Of Obstetrics and Gynaecology, Chalmeda Anand Rao Institute of Medical Sciences, Karimnagar, Telangana, India.

${ }^{3}$ Professor and HOD in Department Of Obstetrics and Gynaecology, Chalmeda Anand Rao Institute Of Medical Sciences, Karimnagar, Telangana, India.

${ }^{4}$ Assistant Professor in Department Of Obstetrics and Gynaecology, Chalmeda Anand Rao Institute Of Medical Sciences, Karimnagar, Telangana, India.

\section{ABSTRACT}

Background: Polycystic ovary syndrome (PCOS) is often characterized by chronic oligo- or anovulation (usually manifested as oligo- or amenorrhea), and hyperandrogenism. 30-40\% of PCOS women have impaired glucose tolerance, and a defect in the insulin signaling pathway (inositol-containing phosphoglycan mediators) seems to be implicated in the pathogenesis of insulin resistance. PCOS patients are subfertile as a consequence of such ovulatory disorders and often need drugs, such as clomiphene citrate or follicle-stimulating hormone, for ovulation induction, which increases the risk of multiple pregnancy and ovarian hyperstimulation syndrome. We hypothesized that the administration of an isoform of inositol (myo-inositol), belonging to the vitamin B complex, would improve the insulin-receptor activity, restoring normal ovulatory function.

Materials and Methods: Twenty-five PCOS women of childbearing age with oligo- or amenorrhea were enrolled in the study. Ovulatory disorder due to PCOS was apparently the only cause of infertility; no tubal defect or deficiency of male semen parameters was found. Myo-inositol combined with folic acid (Inofolic1) $2 \mathrm{~g}$ twice a day was administered continuously. During an observation period of 6 months, ovulatory activity was monitored with ultrasound scan and hormonal profile, and the number of spontaneous menstrual cycles and eventually pregnancies were assessed.

Results: Twenty-two out of the $25(88 \%)$ patients restored at least one spontaneous menstrual cycle during treatment, of whom $18(72 \%)$ maintained normal ovulatory activity during the follow-up period. A total of 10 singleton pregnancies (40\% of patients) were obtained. Nine clinical pregnancies were assessed with fetal heart beat at ultrasound scan. Two pregnancies evolved in spontaneous abortion.

Conclusion: Myo-inositol is a simple and safe treatment that is capable of restoring spontaneous ovarian activity and consequently fertility in most patients with PCOS. This therapy did not cause multiple pregnancy.

KEY WORDS: Myo-Inositol, Polycystic Ovary Syndrome, Ovulation Induction.

Address for correspondence: Dr. Shamili, Post Graduate, Department Of Obstetrics and Gynaecology, Chalmeda Anand Rao Institute Of Medical Sciences, Karimnagar-505001, Telangana, India. E-Mail: shamili.1025@gmail.com

\begin{tabular}{|c|c|c|}
\hline \multicolumn{3}{|c|}{ Online Access and Article Informtaion } \\
\hline \multirow{2}{*}{ Quick Response code } & \multicolumn{2}{|c|}{$\begin{array}{l}\text { International Journal of Integrative Medical Sciences } \\
\qquad \text { www.imedsciences.com }\end{array}$} \\
\hline & $\begin{array}{l}\text { Received: 15-11-2017 } \\
\text { Reviewed: 15-11-2017 }\end{array}$ & $\begin{array}{l}\text { Accepted: 07-12-2017 } \\
\text { Published: 31-03-2018 }\end{array}$ \\
\hline Source of Funding: Self & \multicolumn{2}{|c|}{ Conflicts of interest: None } \\
\hline
\end{tabular}

BACKGROUND

Polycystic ovary syndrome (PCOS) is a medical condition that causes irregular menstrual cycles, chronic anovulation most often manifested as 
oligoor amenorrhea, and androgen excess, with the typical ovarian ultrasound features [1]. It is the most common cause of ovulatory disorders and female infertility, and affects approximately $6-10 \%$ of women in childbearing age [2]. However, its pathogenesis is still poorly understood. Recently, many investigators have focused on the impaired glucose tolerance that affects $30-40 \%$ of patients with PCOS [3]. Insulin plays a direct role in the pathogenesis of hyperandro genemia in PCOS, acting synergistically with luteinizing hormone to enhance the androgen production of theca cells [4]. An inositol phosphoglycan molecule containing D-chiroinositol ( $\mathrm{DCl})$ is known to have a role in activating enzymes that control glucose metabolism [5]. Indeed, a defect in tissue availability or altered metabolism of $\mathrm{DCl}$ or inositol phosphoglycan mediators has been found in PCOS women and may contribute to their insulin resistance $[6,7]$. Isoforms of inositol belong to the vitamin B complex. Epimerization of the six hydroxyl groups of inositol results in the formation of up to nine stereoisomers, including myo-inositol (MI) and $\mathrm{DCl}$. $\mathrm{MI}$ is widely distributed in nature whereas $\mathrm{DCl}$, the product of epimerization of the $\mathrm{C} 1$ hydroxyl group of $\mathrm{MI}$, is relatively rare [8].

Elevated concentration of MI in human follicular fluid appears to play a role in follicular maturity and provides a marker of good-quality oocytes [9]. Furthermore, experiments on mouse oocytes showed that supplementation of $\mathrm{MI}$ in the culture medium increased meiotic progression of germinal vesicles by enhancing the intracellular Ca2p oscillation [10]. Thus we hypothesized that the administration of $\mathrm{MI}$, a precursor of $\mathrm{DCl}$, would improve insulin activity and restore ovulatory function and fertility in amenorrheic women with PCOS.

\section{MATERIALS AND METHODS}

A total of 25 women, 28 to 38 age years of age, with PCOS defined by oligo- or amenorrhea (six or fewer menstrual cycles during a period of 1 year), hyperandrogenism (hirsutism, acne or alopecia) or hyperandogenemia (elevated levels of total or free testosterone) and typical ovarian features on ultrasound scan, were enrolled in the study. All patients attended our IVF Unit for infertility that had lasted for more than 14-16 months. Other medical conditions causing ovulatory dysfunction, such as hyperprola-ctinemia or hypothyroidism, or androgen excess, such as adrenal hyperplasia or Cushing's syndrome, were excluded by hormonal tests. All women underwent assessment of tubal patency and all male partners were evaluated with two different semen sample analyses, without finding any defect. Anovulation was ascertained by weekly plasma progesterone concentration $52.5 \mathrm{ng} / \mathrm{ml}$. Thus, at the end of diagnostic procedures, it was determined that the most likely cause of the couple's subfertility was ovulation dysfunction only. PCOS women were treated orally with MI 2 g plus folic acid $200 \mathrm{mg}$ as soluble powder, twice daily, continuously, until the end of the study or a positive pregnancy test. Patients were instructed to register their menstrual bleeding throughout the follow-up period of 6 months. Furthermore, in order to evaluate the restoration of spontaneous ovarian activity, weekly determination of serum progesterone and testosterone levels, as well as transvaginal ultrasound scan documenting the presence of follicular growth or luteal cyst, were performed after the first menstrual cycle. Pre- and post-treatment hormone concentrations were statistically compared using the two-tailed t test. Moreover, eventual pregnancies were confirmed by a positive test for plasma b-human chorionic gonadotropin and ascertainment of a fetal heart beat on ultrasound scan.

\section{RESULTS}

Baseline clinical and biochemical features of the PCOS patients are reported in Table I. The outcome of treatment is shown in Tables I and II. After a mean of $34.6+5.5$ days of $\mathrm{MI}$ administration, 22 out of the 25 women (88\%) had a first menstrual cycle. Eighteen of these 22 patients presented monthly menstruations during the followup period. All of them maintained spontaneous ovulation activity, documented by follicular growth and increased serum progesterone concentrations in the luteal phase (mean $10.5+1.8 \mathrm{ng} / \mathrm{ml}$ ). Furthermore, after treatment with $\mathrm{MI}$, these women showed significantly decreased concentrations of serum total testosterone $(95.6+8.5$ vs. $45.2+6.7 \mathrm{ng} /$ $\mathrm{dl} ; \mathrm{p} 1 / 40.003)$ and free testosterone $(1.0+0.8$ vs. $0.38+0.1 \mathrm{ng} / \mathrm{dl} ; \mathrm{p} 1 / 40.005)$. The length of 
successive cycles was improved to $31.7+3.2$ days. Two out of the 22 women showed only a follicular development on ultrasound without progesterone elevation during weekly blood sampling, while two women did not have any further ovarian activity after the first cycle. During the observational period of 6 months a total of ten biochemical pregnancies occurred. Nine of the ten were singleton pregnancies documented at ultrasound scan, while one of them was a biochemical abortion. One out of the nine pregnancies evolved in a spontaneous abortion at 7 weeks of gestation. No multiple pregnancy was noted.

Table 1: Clinical and biochemical features of the patients.

\begin{tabular}{|c|c|c|}
\hline Parameter & Baseline & After myo-inositol \\
\hline Age (years) & $32+4$ & \\
\hline Body mass index (kg/m2) & $28.5+2.4$ & \\
\hline $\begin{array}{c}\text { Follicle-stimulating } \\
\text { hormone (mUl/ml) }\end{array}$ & $4.5+2.8$ & \\
\hline $\begin{array}{c}\text { Luteinizing hormone } \\
\text { (mUl/ml) }\end{array}$ & $6.3+3.1$ & \\
\hline Prolactin (ng/ml) & $19.1+2.7$ & $10.5+1.8$ \\
\hline $\begin{array}{c}\text { Thyroid-stimulating } \\
\text { hormone }\end{array}$ & $1.78+0.85$ & \\
\hline $\begin{array}{c}\text { Serum progesterone } \\
\text { (ng/ml) }\end{array}$ & $1.8+0.7$ & $45.2+6.7 *$ \\
\hline $\begin{array}{c}\text { Serum total testosterone } \\
\text { (ng/dl) }\end{array}$ & $95.6+8.5$ & $0.38+0.1$ \\
\hline $\begin{array}{c}\text { Serum free testosterone } \\
\text { (ng/dl) }\end{array}$ & $1.0+0.8$ & $205+28$ \\
\hline $\begin{array}{c}\text { Serum androstenedione } \\
\text { (ng/dl) }\end{array}$ & $230+35$ & \\
\hline
\end{tabular}

Table 2: Outcome of treatment with myo-inositol.

\begin{tabular}{|l|c|}
\hline No. of patients treated & $25(72)$ \\
\hline $\begin{array}{l}\text { No. of patients with menstrual cycle after treatment } \\
\text { (\% of patients) }\end{array}$ & $22(88)$ \\
\hline $\begin{array}{l}\text { No. of patients with restored monthly ovulation (\% of } \\
\text { patients) }\end{array}$ & 18 \\
\hline No. of pregnancies & 10 \\
\hline No. of pregnancies/no. of treated patients (\%) & 40 \\
\hline $\begin{array}{l}\text { No. of pregnancies/no. patients with restored } \\
\text { monthly ovulation (\%) }\end{array}$ & 55 \\
\hline No. of abortions (\% of pregnancies) & $2(20)$ \\
\hline Multiple pregnancy & 0 \\
\hline
\end{tabular}

DISCUSSION

PCOS is one of the most common endocrine disorders affecting women. Insulin resistance and hyperinsulinemia are strictly inherent to the phenotype of a high proportion of women with PCOS. A defect in insulin action has been suspected, particularly as consequence of a deficiency of $\mathrm{DCl}$, a component of inositol phosphoglycan. Chronic anovulation is often the main cause of infertility in patients of reproductive age. It is well known that ovulation induction is a complex issue owing to the increased risk of ovarian hyperstimulation syndrome and multiple pregnancy $[11,12]$. Clomiphene citrate, an antiestrogen, is the common first-choice drug in women with newly diagnosed PCOS, while insulin-lowering medications represent novel therapies for restoring spontaneous ovulation $[13,14]$.

The efficacy of metformin is still debated, both alone and in association with clomiphene citrate $[15,16]$. Metformin treatment is associated with a higher incidence of side-effects such as nausea, vomiting and other gastrointestinal disturbances [17]. DCl administration increases the action of insulin in patients with PCOS, thereby improving ovulatory function and decreasing serum testosterone concentration $[6,18,19]$. $\mathrm{MI}$, a precursor of $\mathrm{DCl}$, is widely distributed in nature whereas $\mathrm{DCl}$ is relatively rare [7]. MI is present in human follicular fluid, where elevated concentrations appear to play a positive role in follicular maturity and provide a marker of goodquality oocytes [9]. Supplementation of $\mathrm{Ml}$ in culture medium increased meiotic progression of germinal vesicles in mouse oocytes by enhancing the intracellular Ca2p oscillation [10].

However, no data exist on therapy with $\mathrm{MI}$ in anovulatory women of reproductive age. Our study demonstrated that MI oral supplementation restores spontaneous ovulation and menstrual cycles, and increases progesterone secretion in the luteal phase, in most infertile patients with PCOS. The present results are in line with other studies evaluating insulin-sensitizing agents in monotherapy or in association with clomiphene citrate $[7,13,14,16-18]$, suggesting the positive effect that MI plays on spontaneous ovarian activity. Furthermore, we found that $\mathrm{MI}$ therapy is able to reduce serum testosterone, both total and free, as already demonstrated with $\mathrm{DCl}$.

All pregnancies obtained in the follow-up period were singleton, and there was no increased incidence of abortion. In conclusion, 
$\mathrm{MI}$ is a simple and safe treatment that is able to restore spontaneous fertility in most patients with PCOS.

\section{CONCLUSION}

Myo-inositol is a simple and safe treatment that is capable of restoring spontaneous ovarian activity and consequently fertility in most patients with PCOS. This therapy did not cause multiple pregnancy.

\section{ACKNOWLEDGEMENT}

I am very thankful to the patients for providing consent and helping us to publish this study and i am also thankful to Chakmeda Lakshmi Narasimha Rao and director Dr.V.Suryanarayana Reddy for supporting this study

\section{REFERENCES}

[1]. Ehrmann DA. Polycystic ovary syndrome. N Engl J Med 2005;352:1223-1236.

[2]. Franks S. Polycystic ovary syndrome. N Engl J Med 1995;333:853-861.

[3]. Ehrmann DA, Barnes RB, Rosenfield RL, Cavaghan MK, Imperial J. Prevalence of impaired glucose tolerance and diabetes in women with polycystic ovary syndrome. Diabetes Care 1999;22:141-146.

[4]. Baillargeon JP, Nestler JE. Polycystic ovary syndrome: a syndrome of ovarian hypersensitivity to insulin? J Clin Endocrinol Metab 2006;91:22-24.

[5]. Larner J. Multiple pathways in insulin signaling fitting the covalent and allosteric puzzle pieces together. Endocr J 1994;2:167-171.

[6]. Baillargeon JP, Diamanti-Kandarakis E, Ostlund RE $J \mathrm{~J}$, Apridonidze T, luorno MJ, Nestler JE. Altered Dchiroinositol urinary clearance in women with polycystic ovary syndrome. Diabetes Care 2006;29:300305.

[7]. Iuorno MJ, Jakubowicz DJ, Baillargeon JP, Dillon $\mathrm{P}$, Gunn RD, Allan G, Nestler JE. Effect of D-chiro-inositol in lean women with the polycystic ovary syndrome. Endocr Pract 2002;8:417-423.

[8]. Yoshida K, Yamaguchi M, Morinaga T, Ikeuchi M, Kinehara M, Ashida H. Genetic modification of Bacillus subtilis for production of D-chiro-inositol, an investigation drug candidate for treatment of type 2 diabetes and polycystic ovary syndrome. Appl Environ Microbiol 2006;72:1310-1315.
[9]. Chiu TT, Rogers MS, Law EL, Briton-Jones CM, Cheung LP, Haines CJ. Follicular fluid and serum concentrations of myo-inositol in patients undergoing IVF: relationship with oocyte quality. Human Reprod 2002;17:1591-1596.

[10]. Chiu TT, Rogers MS, Briton-Jones C, Haines C. Effect of myo-inositol on the in-vitro maturation and subsequent development of mouse oocytes. Human Reprod 2003;18: 408-416.

[11]. Tummon I, Gavrilova-Jordan L, Allemand MC, Session D. Polycystic ovaries and ovarian hyperstimulation syndrome: a systematic review. Acta Obstet Gynecol Scand 2005;84: 611-616.

[12]. Battaglia C, Mancini F, Persico N, Zaccaria V, de Aloysio D. Ultrasound evaluation of PCO, PCOS and OHSS. Reprod Biomed Online 2004;9:614-619.

[13]. Cheang KI, Nestler JE. Should insulin-sensitizing drugs be used in the treatment of polycystic ovary syndrome? Reprod Biomed Online 2004;8:440-447.

[14]. Baillargeon JP. Use of insulin sensitizers in polycystic ovarian syndrome. Curr Opin Investig Drugs 2005;6:1012- 1022.

[15]. Legro RS, Barnhart HX, Schlaff WD, Carr BR, Diamond MP, Carson SA, Steinkampf MP, Coutifaris C, McGovern PG, Cataldo NA, et al.; Cooperative Multicenter Reproductive Medicine Network. Clomiphene, metformin, or both for infertility in the polycystic ovary syndrome. N Engl J Med 2007;356:551-566.

[16]. Pesant $\mathrm{MH}$, Baillargeon JP. Ovulation induction in polycystic ovary syndrome - how do metformin and clomifene citrate compare? Nat Clin Pract Endocr Metab 2007;3:512-513.

[17]. Lord JM, Flight IH, Norman RJ. Metformin in polycystic ovary syndrome: systematic review and metaanalysis. B Med J 2003;327:951-957.

[18]. Nestler JE, Jakubowicz DJ, Reamer P, Gunn RD, Allan G. Ovulatory and metabolic effects of D-chiro-inositol in the polycystic ovary syndrome. N Engl J Med 1999;340:1314- 1320.

[19]. Gerli S, Mignosa M, Di Renzo GC. Effects of inositol on ovarian function and metabolic factors in women with PCOS: a randomized double blind placebo-controlled trial. Eur Rev Med Pharmacol Sci 2003; 7:151-159.

How to cite this article: Madhavi. G.B., Shamili. G, Ramadevi. E, Jyothi. ROLE OF MYO-INOSITOL IN PATIENTS WITH POLYCYSTIC OVARY SYNDROME. Int J Intg Med Sci 2018;5(3):583-586. DOI: 10.16965/ ijims.2017.117 